\title{
Preliminary Study on Phytoplankton Distribution Changes Monitoring for the Intensive Study Area of the Ariake Sea, Japan Based on Remote Sensing Satellite Data
}

\author{
Kohei Arai \\ Graduate School of Science and Engineering \\ Saga University \\ Saga City, Japan
}

\author{
Toshiya Katano \\ Institute of Lowland and Marine Research \\ Saga University \\ Saga City Japan
}

\begin{abstract}
Phytoplankton distribution changes in the Ariake Sea areas, Japan based on remote sensing satellite data is studied. Through experiments with Terra and AQUA MODIS data derived chlorophyll-a concentration and suspended solid as well as truth data of chlorophyll-a concentration together with meteorological data and tidal data which are acquired 7 months from October 2012 to April 2013, it is found that strong correlation between the truth data of chlorophyll-a and MODIS derived chlorophyll-a concentrations with $R$ square value ranges from 0.677 to 0.791 . Also it is found that the relations between ocean wind speed and chlorophyll-a concentration as well as between tidal effects and chlorophyll-a concentration. Meanwhile, there is a relatively high correlation between sunshine duration a day and chlorophyll-a concentration.
\end{abstract}

Keywords-chlorophyl-a concentration; suspended solid; ocean winds.

\section{INTRODUCTION}

Due to red tide contaminations, water color is changed by an algal bloom. In accordance with increasing of phytoplankton concentration, sea surface color changes from blue to green as well as to red or brown depending on the majority of phytoplankton (Dierssen et al, 2006) so that it is capable to detect red tide using this color changes [1].

MODIS ocean color bands data is used for red tide detection. An iterative approach (Arnone et al., 1998 [2]; Stumpf et al., 2003 [3]) for sediment-rich waters, based on the Gordon and Wang (1994) algorithm [4], is used to correct for the atmospheric interference in the six ocean color bands in turbid coastal waters to obtain water leaving radiance, which are then used in the band-ratio algorithm (O'Reilly et al., 2000 [5]) to estimate Chlorophyll in unit of $\mathrm{mg} \mathrm{m}^{-3}$. Also suspended solid is estimated with two bands algorithm (visible minus near infrared bands data). The multi-channels of red tide detection algorithms (in the formula of $C=\left(R_{i}-R_{j}\right) /\left(R_{k}-R_{l}\right)$ where $R_{i}, R_{j}, R_{k}$ and $R_{l}$ are the reflectivity derived from bands $i, j, k$ and $l$.) are proposed. Also learning approaches based on k-nearest neighbors, random forests and support vector machines have been proposed for red tide detection with Moderate Resolution Imaging Spectro-radiometer: MODIS satellite images (Weijian C.,et al.,2009) [6].
Satellite based red tide detection does work under a fine weather condition but not under cloudy and rainy conditions obviously. Furthermore, revisit period of fine resolution of radiometer onboard satellite orbits are longer than typical red tide propagations so that it is not enough observation frequency if only remote sensing satellite is used for red tide detections. Therefore satellite-and ground-based red tide monitoring system is proposed [7]. In the ground based red tide monitoring system, green colored filtered camera and polarization camera are featured for detection of red tide and discrimination of red tide types [8].

The Ariake Sea is the largest productive area of Nori (Porphyra yezoensis) in Japan. In winters of 2012 and 2013, a massive diatom bloom occurred in the Ariake Sea, Japan (Ito et al. 2013). In case of above red tides, bloom causative was Eucampia zodiacus. This bloom had been firstly developed at the eastern part of the Ariake Sea. However, as the field observation is time-consuming, information on the developing process of the red tide, and horizontal distribution of the red tide has not yet been clarified in detail. To clarify the horizontal distribution of red tide, and its temporal change, remote sensing using satellite data is quite useful.

In this paper, the chlorophyll-a concentration algorithm developed for MODIS is firstly validated. Then apply the algorithm to MODIS data which are acquired at the Ariake Sea areas, Japan specifically. Also the relations between tidal effects and chlorophyll-a concentration as well as between ocean wind speed and chlorophyll-a concentration together with between sunshine duration a day and chlorophyll-a concentration.

In the next section, the method and procedure of the experimental study is described followed by experimental data and estimated results. Then conclusion is described with some discussions.

\section{METHOD AND PROCEDURE}

\section{A. The Procedure}

The procedure of the experimental study is as follows, 
1) Gather the truth data of chlorophyll-a concentration measured at the observation towers in the Ariake Sea areas together with the corresponding areas of MODIS derived chlorophyll-a concentration,

2) Gather the meteorological data which includes sunshine duration a day, ocean wind speed and direction, tidal heights,

3) Correlation analysis between the truth data and MODIS derived chlorophyll-a concentration as well as between geophysical parameters, ocean wind speed, sunshine duration a day, tidal heights and chlorophyll-a concentration is made.

\section{B. MODIS}

MODIS stands for The Moderate Resolution Imaging Spectro-radiometer which allows observations of the earth's surface with a variety of wavelength regions ranges from visible to thermal infrared with spatial resolution of 250,500 and 1000 meters. Major specifications of MODIS are shown in Table 1 and 2.

MODIS is carried on Terra and AQUA satellites with local mean time of 10:30 a.m. and 1:30 p.m. with $2330 \mathrm{~km}$ of swath width. Therefore, it may cover entire globe within a day. MODIS data is applicable to land surface, ocean surface, and atmosphere observations as is shown in Table 2. In particular for ocean surface observations, bands 8 to 16 data are useful.

TABLE I. MAJOR SPECIFICATIONS OF MODIS ${ }^{1}$

\begin{tabular}{|c|c|}
\hline Orbit: & $\begin{array}{l}705 \mathrm{~km}, 10: 30 \text { a.m. descending node (Terra) or 1:30 p.m. } \\
\text { ascending node (Aqua), sun-synchronous, near-polar, } \\
\text { circular }\end{array}$ \\
\hline Scan Rate: & $20.3 \mathrm{rpm}$, cross track \\
\hline $\begin{array}{c}\text { Swath } \\
\text { Dimensions: }\end{array}$ & $2330 \mathrm{~km}$ (cross track) by $10 \mathrm{~km}$ (along track at nadir) \\
\hline Telescope: & $\begin{array}{c}17.78 \mathrm{~cm} \text { diam. off-axis, afocal (collimated), with } \\
\text { intermediate field stop }\end{array}$ \\
\hline Size: & $1.0 \times 1.6 \times 1.0 \mathrm{~m}$ \\
\hline Weight: & $228.7 \mathrm{~kg}$ \\
\hline Power: & $162.5 \mathrm{~W}$ (single orbit average) \\
\hline Data Rate: & 10.6 Mbps (peak daytime); 6.1 Mbps (orbital average) \\
\hline Quantization: & 12 bits \\
\hline $\begin{array}{c}\text { Spatial } \\
\text { Resolution: }\end{array}$ & $\begin{array}{c}250 \mathrm{~m} \text { (bands 1-2) } \\
500 \mathrm{~m} \text { (bands 3-7) } \\
1000 \mathrm{~m} \text { (bands 8-36) }\end{array}$ \\
\hline Design Life: & 6 years \\
\hline
\end{tabular}

TABLE II. APPLICATION OF MODIS SENSOR DATA ${ }^{2}$

\begin{tabular}{|c|c|c|c|c|}
\hline Primary Use & Band & Bandwidth ${ }^{1}$ & $\begin{array}{c}\text { Spectral } \\
\text { Radiance }^{2}\end{array}$ & $\begin{array}{c}\text { Required } \\
\text { SNR }^{-3}\end{array}$ \\
\hline \multirow{2}{*}{$\begin{array}{c}\text { Land/Cloud/Aerosols } \\
\text { Boundaries }\end{array}$} & 1 & $620-670$ & 21.8 & 128 \\
\hline & 2 & $841-876$ & 24.7 & 201 \\
\hline Land/Cloud/Aerosols & 3 & $459-479$ & 35.3 & 243 \\
\hline
\end{tabular}

\footnotetext{
${ }^{1}$ http://modis.gsfc.nasa.gov/about/specifications.php

${ }^{2}$ http://modis.gsfc.nasa.gov/about/specifications.php
}

\begin{tabular}{|c|c|c|c|c|}
\hline \multirow[t]{4}{*}{ Properties } & 4 & $545-565$ & 29.0 & 228 \\
\hline & 5 & $1230-1250$ & 5.4 & 74 \\
\hline & 6 & $1628-1652$ & 7.3 & 275 \\
\hline & 7 & $2105-2155$ & 1.0 & 110 \\
\hline \multirow{9}{*}{$\begin{array}{l}\text { Ocean Color/ } \\
\text { Phytoplankton/ } \\
\text { Biogeochemistry }\end{array}$} & 8 & $405-420$ & 44.9 & 880 \\
\hline & 9 & $438-448$ & 41.9 & 838 \\
\hline & 10 & $483-493$ & 32.1 & 802 \\
\hline & 11 & $526-536$ & 27.9 & 754 \\
\hline & 12 & $546-556$ & 21.0 & 750 \\
\hline & 13 & $662-672$ & 9.5 & 910 \\
\hline & 14 & $673-683$ & 8.7 & 1087 \\
\hline & 15 & $743-753$ & 10.2 & 586 \\
\hline & 16 & $862-877$ & 6.2 & 516 \\
\hline \multirow{3}{*}{$\begin{array}{l}\text { Atmospheric } \\
\text { Water Vapor }\end{array}$} & 17 & $890-920$ & 10.0 & 167 \\
\hline & 18 & $931-941$ & 3.6 & 57 \\
\hline & 19 & $915-965$ & 15.0 & 250 \\
\hline Primary Use & Band & Bandwidth $^{1}$ & \begin{tabular}{|c|} 
Spectral \\
Radiance $^{2}$
\end{tabular} & $\begin{array}{c}\text { Required } \\
\text { NE[delta]T }(K)^{4}\end{array}$ \\
\hline \multirow{4}{*}{$\begin{array}{l}\text { Surface/Cloud } \\
\text { Temperature }\end{array}$} & 20 & $3.660-3.840$ & $0.45(300 \mathrm{~K})$ & 0.05 \\
\hline & 21 & $3.929-3.989$ & $2.38(335 \mathrm{~K})$ & 2.00 \\
\hline & 22 & $3.929-3.989$ & $0.67(300 \mathrm{~K})$ & 0.07 \\
\hline & 23 & $4.020-4.080$ & $0.79(300 \mathrm{~K})$ & 0.07 \\
\hline \multirow{2}{*}{$\begin{array}{l}\text { Atmospheric } \\
\text { Temperature }\end{array}$} & 24 & $4.433-4.498$ & $0.17(250 \mathrm{~K})$ & 0.25 \\
\hline & 25 & $4.482-4.549$ & $0.59(275 \mathrm{~K})$ & 0.25 \\
\hline \multirow{3}{*}{$\begin{array}{l}\text { Cirrus Clouds } \\
\text { Water Vapor }\end{array}$} & 26 & $1.360-1.390$ & 6.00 & $150(\mathrm{SNR})$ \\
\hline & 27 & $6.535-6.895$ & $1.16(240 \mathrm{~K})$ & 0.25 \\
\hline & 28 & $7.175-7.475$ & $2.18(250 \mathrm{~K})$ & 0.25 \\
\hline Cloud Properties & 29 & $8.400-8.700$ & $9.58(300 \mathrm{~K})$ & 0.05 \\
\hline Ozone & 30 & $9.580-9.880$ & $3.69(250 \mathrm{~K})$ & 0.25 \\
\hline \multirow{2}{*}{$\begin{array}{c}\text { Surface/Cloud } \\
\text { Temperature }\end{array}$} & 31 & $10.780-11.280$ & $9.55(300 \mathrm{~K})$ & 0.05 \\
\hline & 32 & $11.770-12.270$ & $8.94(300 \mathrm{~K})$ & 0.05 \\
\hline \multirow{4}{*}{$\begin{array}{l}\text { Cloud Top } \\
\text { Altitude }\end{array}$} & 33 & $13.185-13.485$ & $4.52(260 \mathrm{~K})$ & 0.25 \\
\hline & 34 & $13.485-13.785$ & $3.76(250 \mathrm{~K})$ & 0.25 \\
\hline & 35 & $13.785-14.085$ & $3.11(240 \mathrm{~K})$ & 0.25 \\
\hline & 36 & $14.085-14.385$ & $2.08(220 \mathrm{~K})$ & 0.35 \\
\hline 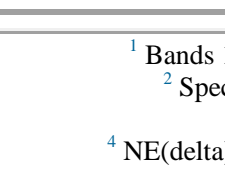 & 19 & $\begin{array}{l}\text { nm; Bands } 2 \\
\text { ce values are ( } \\
\text { Signal-to-noise } \\
\text { equivalent tem }\end{array}$ & $\begin{array}{l}\text { to } 36 \text { are } \\
/ / \mathrm{m}^{2}-\mu \mathrm{m} \\
\text { ratio } \\
\text { erature d }\end{array}$ & $\mathrm{m}$ \\
\hline
\end{tabular}

Note: Performance goal is $30-40 \%$ better than required

There are following many ocean related products ${ }^{3}$,

Angstrom Exponent

Aerosol Optical Thickness

\footnotetext{
${ }^{3}$ http://oceancolor.gsfc.nasa.gov/
} 
Chlorophyll a

Downwelling diffuse attenuation coefficient at 490

$\mathrm{nm}$

Level 2 Flags

Photosynthetically Available Radiation

Particulate Inorganic Carbon

Particulate Organic Carbon

Sea Surface Temperature Quality

Sea Surface Temperature Quality - 4um

Remote Sensing Reflectance

Sea Surface Temperature

Sea Surface Temperature 4um

In this study, chlorophyll-a product is used for the experiments.

\section{The Intensive Study Areas}

Figure 1 shows the intensive study areas in the Ariake Sea area, Kyushu, Japan.

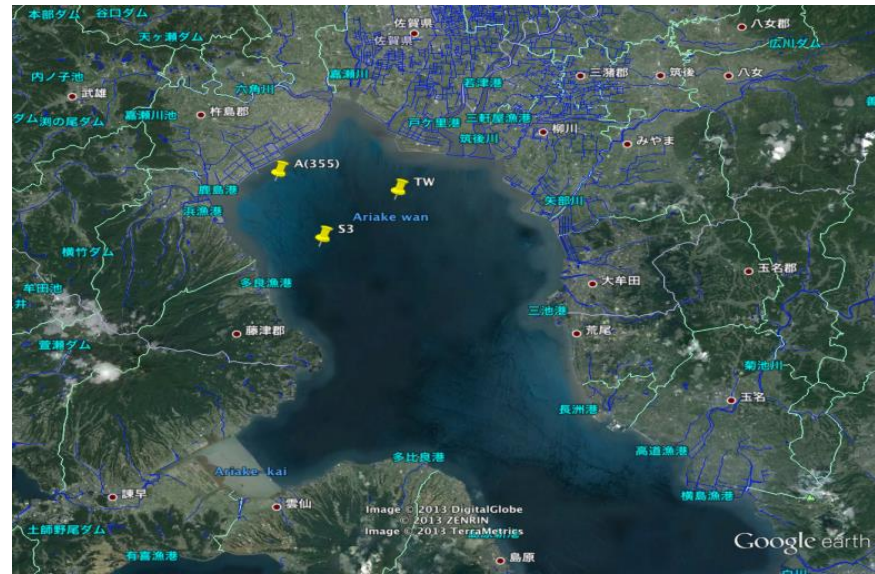

Fig 1. The Intensive study areas (Yellow pins shows the areas)

There are three observation tower points, TW, S, and A. TW is closely situated to the Saga Ariake Airport and is situated near the river mouth. On the other hand, A is situated most closely to the coastal area while $\mathrm{S}$ is situated in the middle point of the Ariake Sea width and is situated most far from the coastal areas and river mouths.

\section{EXPERIMENTS}

\section{A. The Data Used}

The truth data of chlorophyll-a concentration measured at the observation towers in the intensive study areas in the Ariake Sea areas together with the corresponding areas of MODIS derived chlorophyll-a concentration which area acquired for the observation period of 7 months during from October 2012 to April 2013 are used for the experiments. Also, the meteorological data which includes sunshine duration, ocean wind speed and direction, tidal heights which are acquired for the 7 months are used for the experiments.

Figure 2 shows an example of the chlorophyll-a concentration image which is derived from MODIS data which is acquired on 25 February 2013.
The chlorophyll-a concentration measured at the tower, TW ranges from 52 to $64 \mathrm{ug} / \mathrm{l}$ (the highest value in the 7 months). This is red tide (Phytoplankton) blooming period. Such this MODIS derived chlorophyll-a concentration data are available almost every day except cloudy and rainy conditions.

Blooming is used to be occurred when the seawater becomes nutrient rich water, calm ocean winds, long sunshine duration after convection of seawater (vertical seawater current from the bottom to sea surface). Therefore, there must exists relations between the geophysical parameters, ocean wind speed, sunshine duration, tidal heights and chlorophyll-a concentration.

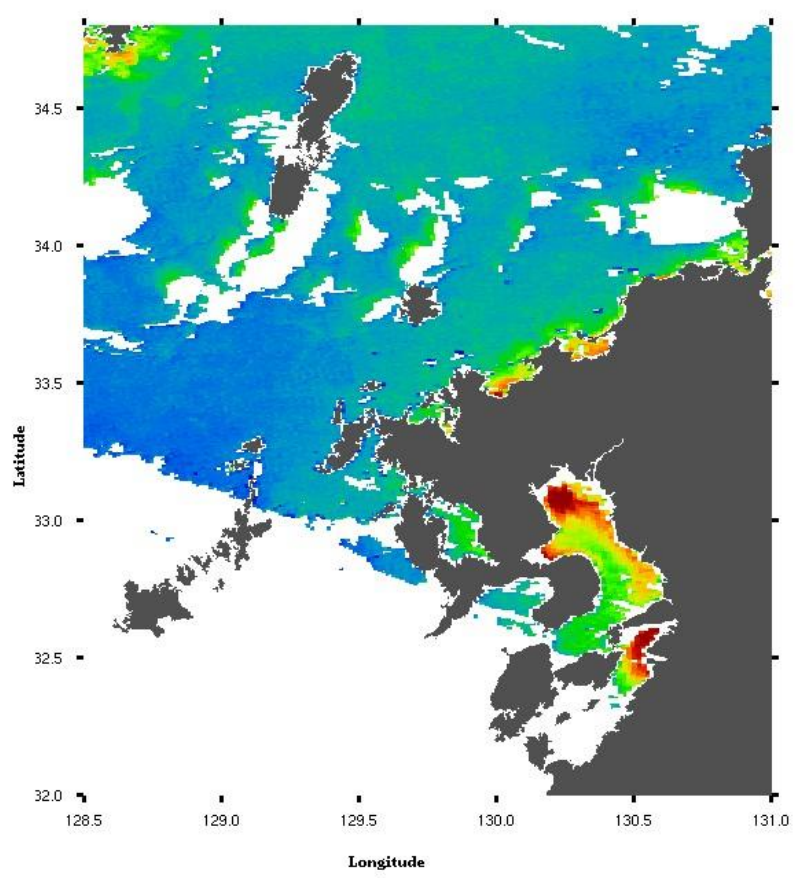

Fig 2. An example of the chlorophyll-a concentration image which is derived from MODIS data which is acquired on 25 February 2013

\section{B. The Relation Between Truth Data and MODIS Derived Colorophyl-a Concentrations}

In order to check validity of the chlorophyll-a concentration estimation algorithm, the relation between truth and MODIS derived chlorophyll-a concentration is investigated. Figure 3 shows the relation between these for intensive study area of S while Figure 4 shows the relation for intensive study area of TW.

In the figures, $\mathrm{L}$ and $\mathrm{H}$ denote Low and High chlorophyll-a concentration of the day. Also Ch-a denotes chlorophyll-a concentration in unit of $\mu \mathrm{g} / \mathrm{l}$. Linear (L) denotes linear regression line for minimum chlorophyll-a concentration of the day while Linear $(\mathrm{H})$ denotes that for maximum chlorophyll-a concentration of the day.

\section{Trend Analysis}

MODIS derived chlorophyll-a concentration which are acquired from January 42013 to February 282013 are shown in Figure 5. 


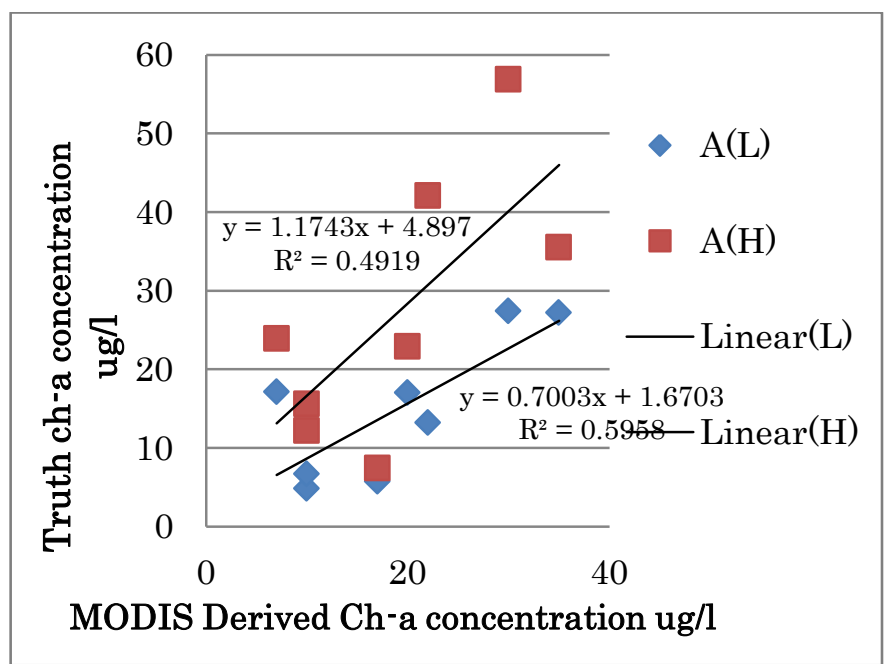

Fig 3. Relation between truth and MODIS derived chlorophyll-a concentrations for the intensive study area of $\mathrm{S}$

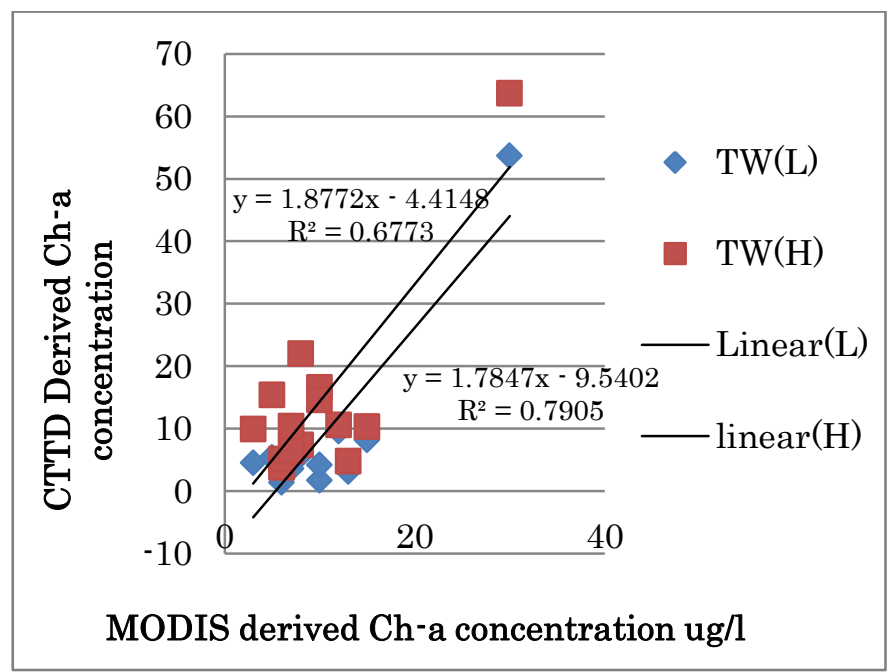

Fig 4. Relation between truth and MODIS derived chlorophyll-a concentrations for the intensive study area of TW

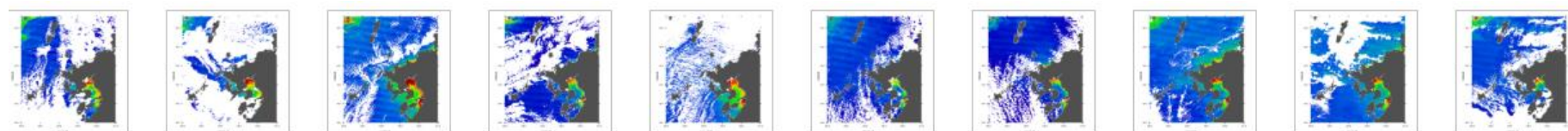

1D02HKM_J2013010.. MODO2HKM_J2013010... MOD02HKM_J2013011... MOD02HKM_J2013011... MODO2HKM_J2013011... MOD02HKM_J2013011... MOD02HKM_J2013012... MOD02HKM_J2013012... MOD02HKM_J2013013... MOD02HKM_J20130؛

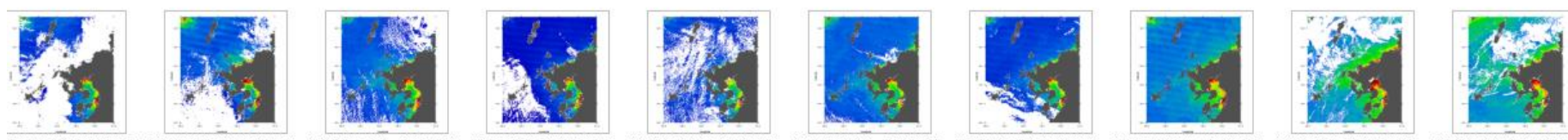

ID02HKM_J2013020... MODO2HKM_J2013021... MOD02HKM_J2013021... MOD02HKM__J2013022... MODO2HKM_J2013022.. MOD02HKM_J2013022.. MOD02HKM_J2013022... MOD02HKM_J2013022.. MYD02HKM_J2012100... MYD02HKM_J20121C

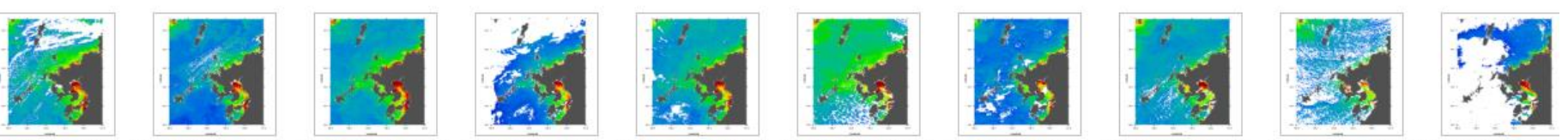

D02HKM_J2012101... MYD02HKM_J2012101... MYDO2HKM_J2012101... MYDO2HKM_J2012102.. MYD02HKM_J2012102... MYD02HKM_J2012102... MYD02HKM_J2012102.. MYO02HKM_J2012102.. MYD02HKM_J2012110... MYD02HKM_J201211
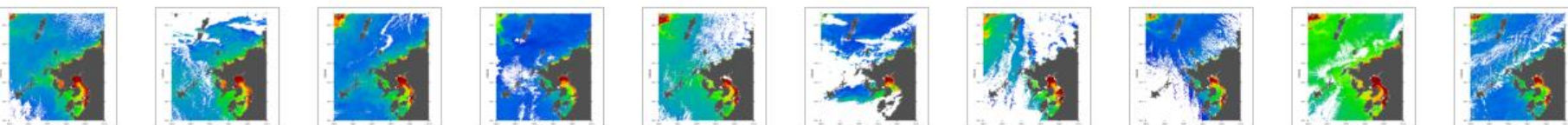

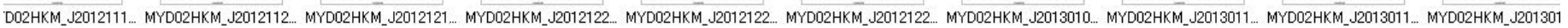
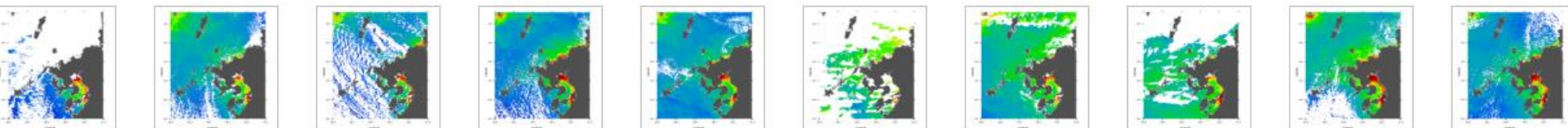

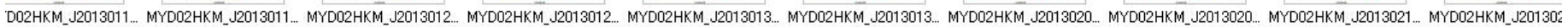
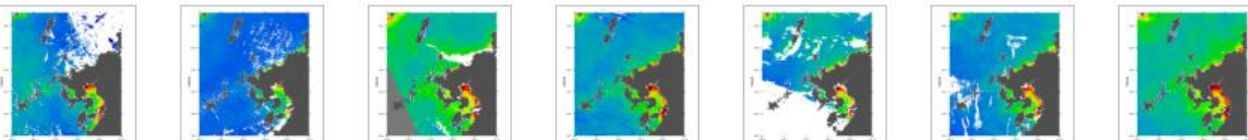

D02HKM_J2013021... MYD02HKM_J2013022... MYD02HKM_J2013022... MYD02HKM_J2013022... MYD02HKM_J2013022... MYD02HKM_J2013022... MYD02HKM_J20130228 $0400 \mathrm{AQ} 0050100561$ A

Fig 5. MODIS derived chlorophyll-a concentration in the intensive study areas which are acquired from January 42013 to February 282013

A massive red tide by large diatom of Eucampia zodiacus occurred from February to April, 2013 in the innermost are of the Ariake Sea. The bloom developing process are clearly detected in Figure 5.
In the first half of the Figure 5, surface chlorophyll-a concentration was low in the sea; however, it obviously increased in the middle of the Figure 5. 
Finally, in the later half of the figure, quite high concentrations of chlorophyll-a were detected in the innermost area of the sea, as the Eucampia population developed. To clarify the developing mechanism of this red tide, other environmental variables such as temperature, salinity, nutrient concentrations should be further investigated.

\section{Relations between geophysical parameters and chlorophyll-a concentrations}

Nutrient rich seawater near the bottom is used to be flown from the sea bottom to the sea surface when the seawater convection is occurred due to ocean wind, and tidal effect. Then chlorophyll-a concentration increases in accordance with sunshine duration with the nutrient rich sea surface water. Therefore, there must exist some relations between the geophysical parameter of ocean wind, tidal effect and sunshine duration.

Figure 6 shows a relatively high relation between accumulated sunshine duration for the past three days and chlorophyll-a concentration. Ocean wind is not so strong, while tidal effect is also not so high. Therefore the relation between accumulated sun appearances time duration is proportional to the truth data of chlorophyll-a concentration.

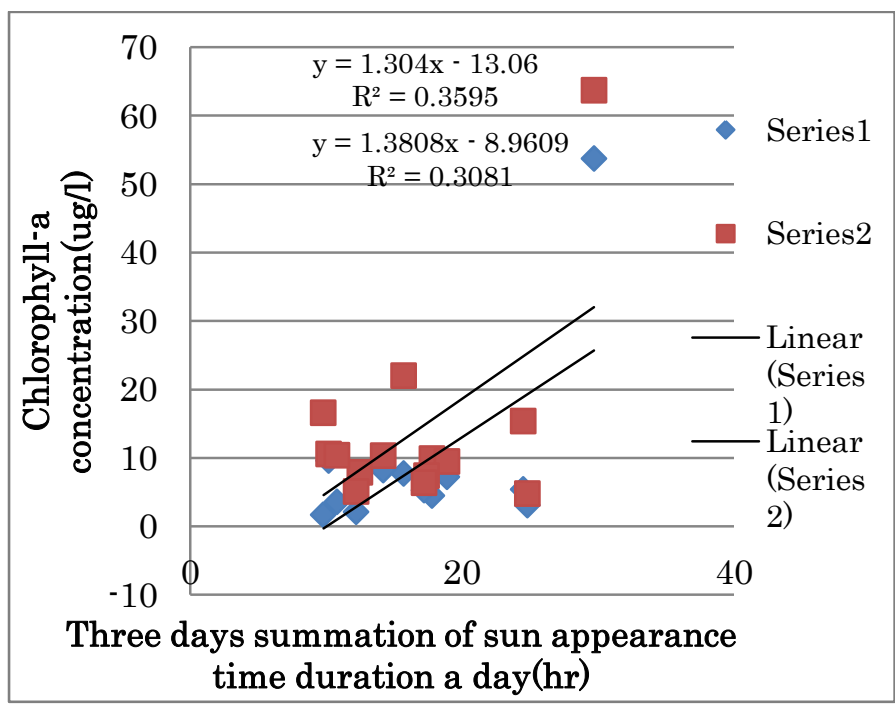

Fig 6. Relation between accumulated sunshine duration a day for the past three days and chlorophyll-a concentration

It can also be said that there are very weak relation between chlorophyll-a concentration and ocean wind as well as sea level difference a day due to the fact that ocean wind is not so high while tidal effect is not so large. Figure 7 shows the relation between chlorophyll-a concentration and accumulated daily averaged ocean wind speed for the past two days.

Meanwhile, Figure 8 shows the relation between chlorophyll-a concentration and sea surface level difference a day while Figure 9 shows the relation between chlorophyll-a concentration and the accumulated sea surface level difference for the past two days.

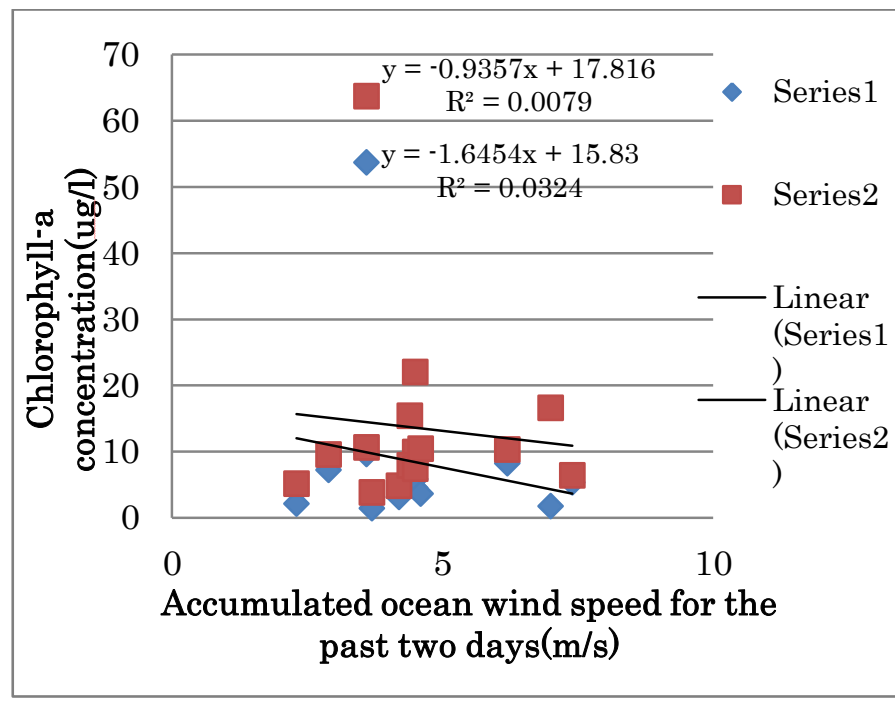

Fig 7. Relation between chlorophyll-a concentration and accumulated daily averaged ocean wind speed for the past two days.

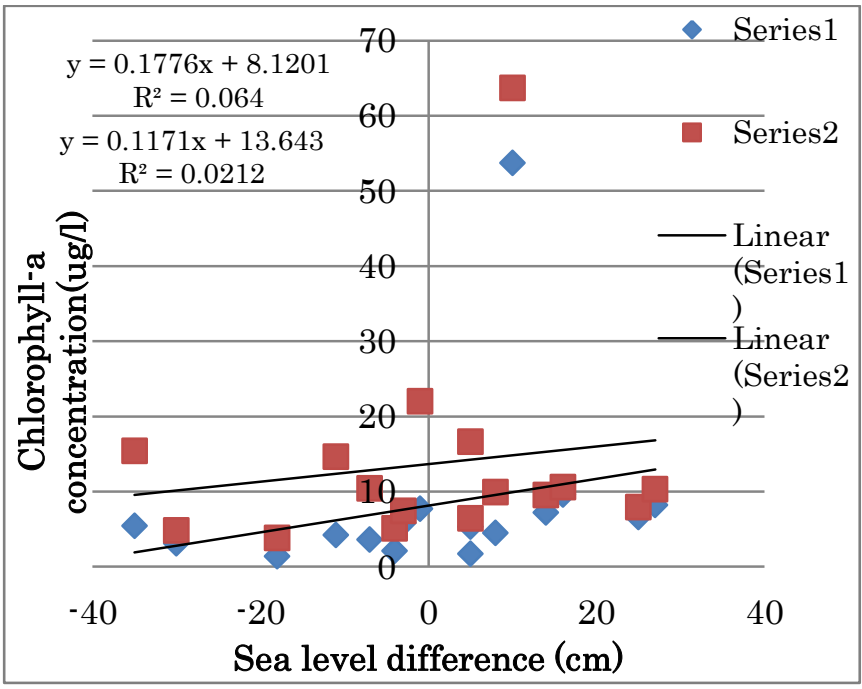

Fig 8. Relation between chlorophyll-a concentration and sea surface level difference a day

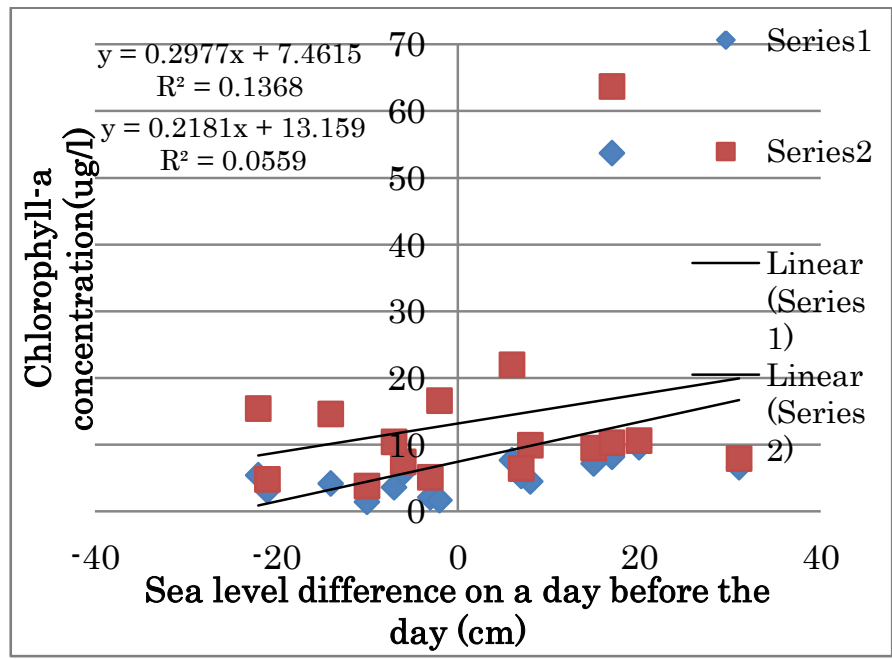

Fig 9. Relation between chlorophyll-a concentration and the accumulated sea surface level difference for the past two days. 
It is confirmed that relation between ocean wind speed and chlorophyll-a concentration is weak. Also, it is confirmed that relation between sea surface level difference a day and chlorophyll-a concentration is weak. It may said that relation between two days accumulated sea surface level difference a day and chlorophyll-a concentration is higher than that between one day sea surface level difference and chlorophyll-a concentration. That is because of the fact that there is time delay of chlorophyll-a increasing after the nutrient rich bottom seawater is flown to the sea surface.

\section{CONCLUSION}

Preliminary study on phytoplankton distribution changes monitoring for the intensive study area of the Ariake Sea, Japan based on remote sensing satellite data is conducted. Phytoplankton distribution changes in the Ariake Sea areas, Japan based on remote sensing satellite data is studied.

Through experiments with Terra and AQUA MODIS data derived chlorophyll-a concentration and suspended solid as well as truth data of chlorophyll-a concentration together with meteorological data and tidal data which are acquired 7 months from October 2012 to April 2013, it is found that strong correlation between the truth data of chlorophyll-a and MODIS derived chlorophyll-a concentrations with $\mathrm{R}$ square value ranges from 0.677 to 0.791 .

Also it is found that the relations between ocean wind speed and chlorophyll-a concentration as well as between tidal effects and chlorophyll-a concentration. Meanwhile, there is a relatively high correlation between sunshine duration a day and chlorophyll-a concentration.

As the results from the experiments, it is found that the followings,

1) the accumulated sun appearances time duration is proportional to the truth data of chlorophyll-a concentration

2) it is confirmed that relation between ocean wind speed and chlorophyll-a concentration is weak,

$3)$ it is confirmed that relation between sea surface level difference a day and chlorophyll-a concentration is weak,

4) it may said that relation between two days accumulated sea surface level difference a day and chlorophyll-a concentration is higher than that between one day sea surface level difference and chlorophyll-a concentration,

5) there is a time delay of chlorophyll-a increasing after the nutrient rich bottom seawater is flown to the sea surface.

\section{ACKNOWLEDGMENT}

The authors would like to thank Dr. Yuichi Hayami of Institute of Lowland and Marine Research, Saga University for his great supports through the experiments.

\section{REFERENCES}

[1] Dierssen H.M., R.M.Kudela, J.P.Ryan, R.C.Zimmerman, Red and black tides: Quantitative analysis of water-leaving radiance and perceived color for phytoplankton, colored dissolved organic matter, and suspended sediments, Limnol. Oceanogr., 51(6), 2646-2659, E 2006, by the American Society of Limnology and Oceanography, Inc., 2006.

[2] Arnone, R. A., Martinolich, P., Gould, R. W., Jr., Stumpf, R., \& Ladner, S., Coastal optical properties using SeaWiFS. Ocean Optics XIV, Kailua Kona, Hawaii, USA, November 10-13, 1998. SPIE Proceedings., 1998.

[3] Stumpf, R. P., Arnone, R. A., Gould Jr., R. W., Martinolich, P. M., \& Martinuolich, V., A partially coupled ocean-atmosphere model for retrieval of water-leaving radiance from SeaWiFS in coastal waters. In S. B. Hooker, \& E. R. Firestone (Eds.), SeaWiFS Postlaunch Tech. Report Series. NASA Technical Memorandum, 2003-206892, vol. 22 (p. 74), 2003.

[4] Gordon, H. R., \& Wang, M., Retrieval of water-leaving radiance and aerosol optical thickness over the oceans with SeaWiFS: A preliminary algorithm. Applied Optics, 33, 443-452, 1994.

[5] O'Reilly, J. E., Maritorena, S., Siegel, D. A., O’Brien, M. C., Toole, D.,Chavez, F. P., et al., Ocean color chlorophyll a algorithms for SeaWiFS, OC2, and OC4: Version 4. In B. Hooker, \& R. Firestone (Eds.), SeaWiFS Postlaunch Tech. Report Series. NASA Technical Memorandum 2000-206892, vol. 11 (p. 2000), 2000.

[6] Weijian C., Hall, L.O., Goldgof, D.B., Soto, I.M., Chuanmin H, Automatic red tide detection from MODIS satellite images, Systems, Man and Cybernetics, 2009. SMC 2009. IEEE International Conference on SMC, 2009.

[7] Kohei Arai and Yasunori Terayama, Polarized radiance from red tide, Proceedings of the SPIE Asia Pacific Remote Sensing, AE10-AE101-14, Invited Paper, 2010

[8] Kohei Arai, Red tides: combining satellite- and ground-based detection. 29 January 2011, SPIE Newsroom. DOI: 10.1117/2.1201012.003267, http://spie.org/x44134.xml?ArticleID $=x 44134$

[9] Graham LE, Wilcox LW. (2000) Algae. pp. 232-68. Prentice Hall. ISBN 0-13-660333-5

[10] Kroger N, Deutzmann R, Sumper M (1999). "Polycationic peptides from diatom biosilica that direct silica nanosphere formation". Science 286 (5442): 1129-32.

[11] Martin-Jezequel V, Hildebrand M, Brzezinski MA (2000). "Silicon metabolism in diatoms: Implications for growth". J Phycol 36: 821-40.

[12] Adl, Sina M.; et al. (2005), "The New Higher Level Classification of Eukaryotes with Emphasis on the Taxonomy of Protists", J. Eukaryot. Microbiol. 52 (5): 429-493

[13] Adl, Sina M.; et al. (2012), "The Revised Classification of Eukaryotes", J. Eukaryot. Microbiol. 59 (5): 429-493

\section{AUTHORS PROFILE}

Kohei Arai, He received BS, MS and PhD degrees in 1972, 1974 and 1982, respectively. He was with The Institute for Industrial Science and Technology of the University of Tokyo from April 1974 to December 1978 also was with National Space Development Agency of Japan from January, 1979 to March, 1990. During from 1985 to 1987, he was with Canada Centre for Remote Sensing as a Post Doctoral Fellow of National Science and Engineering Research Council of Canada. He moved to Saga University as a Professor in Department of Information Science on April 1990. He was a councilor for the Aeronautics and Space related to the Technology Committee of the Ministry of Science and Technology during from 1998 to 2000. He was a councilor of Saga University for 2002 and 2003. He also was an executive councilor for the Remote Sensing Society of Japan for 2003 to 2005. He is an Adjunct Professor of University of Arizona, USA since 1998. He also is Vice Chairman of the Commission "A" of ICSU/COSPAR since 2008. He wrote 30 books and published 500 journal papers 